\title{
The Influence of Equity Incentive on Overinvestment in enterprises: The moderating effect based on the heterogeneity of executive team
}

\author{
Wei Liu ${ }^{1, a^{*}}$, Tingting Yang ${ }^{2, b}$, Xiao Le $e^{3, c}$ \\ ${ }^{1}$ School of Business Administration, Chongqing Technology and Business University, Chongqing, China \\ ${ }^{2}$ School of Business Administration, Chongqing Technology and Business University, Chongqing, China \\ ${ }^{3}$ School of Business Administration, Chongqing Technology and Business University, Chongqing, China
}

\begin{abstract}
This paper empirically examines the moderating effect of executive team heterogeneity on the influence of equity incentive on overinvestment behavior by using the data of Chinese A-share listed companies in Shanghai and Shenzhen from 2014 to 2018. The results show that equity incentive can restrain the overinvestment behavior of enterprises; The greater the age heterogeneity of the senior management team, the weaker the influence of equity incentive on overinvestment will be; The greater the gender heterogeneity of the senior management team, the greater the influence of equity incentive on the overinvestment of enterprises will be. The heterogeneity of executive team education and tenure has no effect on the relationship between equity incentive and overinvestment. The conclusion of this study has some enlightenment on how to construct and optimize the senior management team of listed companies, so that the senior management team can play its role fully and make reasonable and effective investment decisions.
\end{abstract}

\section{Introduction}

How to restrain overinvestment effectively is the core problem of modern enterprise management. According to principal-agent theory, as a kind of long-term incentive equity incentive system, and makes the management goal is consistent with the interests of the shareholders, many scholars think that the senior management team to implement equity incentive can effectively reduce the agency costs associated with investment, curb excessive investment, encourage executives to choose reasonable investment path, thus reducing the efficiency of investment (Belghitar \& Clark, 2015). According to the existing research literature, most of them regard the characteristics of senior management team as homogeneous based on the neoclassical economic theory, focusing on the impact of independent explanatory variables of equity incentive on corporate overinvestment. However, in reality, the characteristics of executive teams are heterogeneous (Liu Yawei, 2015). According to the high-level echelon theory, differences in demographic background characteristics such as gender, age, education, educational background, tenure and work experience will lead to different cognitive biases and behavioral choices in senior management teams, and cognitive biases caused by the characteristics of senior management teams may have an impact on the investment decision-making

\footnotetext{
$\mathrm{a}^{*}$ Corresponding author's e-mail: liu.wei@ctbu.edu.cn

bemai: 1592383370@qq.com, cemail: 1451601935@qq.com
}

process and results. Therefore, this article try to TMT heterogeneity into the same model, from the perspective of TMT heterogeneity, study the effect of equity incentive excessive investment behavior of the enterprise, not only helps to enrich related research theory of equity incentive system, and excessive investment behavior of the enterprise reality and persuasive explanation, according to senior management team to implement equity incentive features for the enterprise provides the basis for policy to curb excessive investment behavior.

\section{Theoretical analysis and hypothesis Proposal}

\subsection{The influence of equity incentive on overinvestment}

In market economy developed countries most of the enterprises have to establish a relatively perfect the equity incentive system, thought of equity incentive as the company's important governance mechanism and the long-term incentive mechanism, can make the executive compensation and corporate performance, the objective function makes the interests of managers and shareholders consistency, thus effectively restrain excessive investment behavior, so the equity incentive is business visual metaphor as "golden handcuffs". Compared with before and after the share reform, the 
implementation of equity incentive can better stimulate the enthusiasm of the senior management team, make investment decisions that are beneficial to the enterprise, and pay more attention to the future investment interests of the enterprise . Equity incentive can effectively reduce the inconsistencies between executives and shareholders and help to maintain long-term convergence of interests between executives and shareholders, thus alleviating principal-agent conflicts between executives and shareholders (Sheikh S, 2012). Song Yuchen et al. (2017) examined the impact of equity incentive plans on investment efficiency of listed companies and found that equity incentive plans on the whole improved investment efficiency of listed companies and could restrain excessive investment behavior of enterprises. Wang Luping et al. (2018) found that the implementation of equity incentive can reduce the overinvestment behavior caused by principal-agent and information asymmetry. Moreover, the greater the equity incentive intensity is, the lower the absolute level of overinvestment in family enterprises will be. Although equity incentive can help enterprises improve the incentive mechanism and mobilize the enthusiasm and creativity of all aspects, it is not effective for any object at all times and is not universally applicable for any enterprise. Wang Zeyuan and Cao Yang (2020) found that equity incentive has a significant inducing effect on overinvestment. Based on this, this paper proposes the following hypothesis:

Hypothesis1: For market-oriented listed companies, reasonable equity incentive can restrain the excessive investment behavior of senior executives.

\subsection{The moderating effect of heterogeneity of senior management team on the influence of equity incentive on overinvestment}

The influence of gender heterogeneity of senior management team on the relationship between equity incentive and overinvestment. Equity incentive is the reallocation of rights, responsibilities, risks and benefits. The incentive target is mainly driven by human behavior, so the incentive effect is affected by gender characteristics. In the face of equity incentive, female executives tend to be cautious and conservative in making investment decisions due to their delicacy, prudence and sensitivity in dealing with things. However, male executives tend to proceed from the overall situation when facing the equity incentive, and are more adventurous than female executives, and even show overconfidence. It means that the greater the gender heterogeneity of the senior management team, the more dissonance the senior management team may have on investment decisions. Overconfident managers are more likely to increase the over-investment behavior of enterprises (Sun Yemeng and Zhang Guitong, 2020). Yang Kun et al. (2019) examined the influence of heterogeneity of executive team on corporate overinvestment behavior and found that different cognitive patterns between the sexes would bring different knowledge and experience, which would lead to communication conflicts between male and female executives and aggravate corporate overinvestment behavior. Therefore, the difference in gender characteristics between female and male executives will lead to different investment decisions when faced with equity incentive. Based on this, this paper proposes the following hypothesis:

Hypothesis2: The greater the gender heterogeneity of the senior management team, the weaker the influence of equity incentive on corporate overinvestment.

The influence of age heterogeneity of senior management teams on the relationship between equity incentive and overinvestment. The greater the age difference among senior executives, the more likely they are to have conflicts of cognitive concepts and values. According to the theory of social identity, senior executives with a younger average age have a strong ability to learn and accept emerging things. In the face of equity incentive, they prefer to take risks and are willing to take risks. They are more inclined to obtain risks and returns, which will lead to overinvestment. Comparatively speaking, senior executives with average age pay more attention to their economic interests and career stability, are more willing to consider risk aversion when faced with equity incentives, and tend to make conservative investment decisions and invest in projects with less risk. Some scholars found that age heterogeneity of senior management team is conducive to improving the investment efficiency of enterprises and restraining the excessive investment behavior of enterprises. Age difference of senior management team members will promote enterprises to make strategic positioning that is conducive to enterprise performance (Yang and Wang,2014). Li Duansheng and Wang Xiaoyan (2019) believe that the older the age heterogeneity of the executive team, the higher the proportion of young members will be, which is conducive to playing complementary functions and promoting enterprises' innovation and investment behaviors. Therefore, age heterogeneity of senior management team may play a moderating role in the relationship between equity incentive and overinvestment. Accordingly, the following hypotheses are proposed:

Hypothesis3: The greater the age heterogeneity of the senior management team, the greater the influence of equity incentive on corporate overinvestment will be.

Influence of educational heterogeneity of senior management team on the relationship between equity incentive and overinvestment. Grasping and decision-making is correct depends on investment opportunities in the senior executives to early to market information processing, opportunity identification and cognitive ability, and executive education background to a certain extent, reflect their cognitive ability and information processing ability, the higher the degree of managers, you can have a keen insight and enough understanding to find and solve the problems existing in the investment, develop the strategy to solve the problem, thus effectively cope with the complex investment decision-making environment; Less educated managers tend to have limited skills. The higher the level of education, the higher the ability of the senior 
management team to process market information and identify opportunities. The greater the cultural differences in the senior management team, the greater the differences in investment decisions. Individuals with the same educational background are more likely to reach consensus and conduct good cooperation (Lin Chaonan and Lin Yi, 2014). Gao Changyuan and Wu Min (2019) believe that executives with higher education pay more attention to details when making decisions, and too much detailed analysis may lead to missing the best opportunity, thus affecting the decision-making efficiency of enterprises. The greater the educational heterogeneity of an executive team, the less smooth the channels of effective communication and communication among team members will be, thus increasing the possibility of friction among team members, easily causing conflicts among team members, and affecting the decision-making efficiency of the executive team. Based on this, this paper proposes the following hypothesis:

Hypothesis4: The greater the educational heterogeneity of the senior management team, the weaker the influence of equity incentive on the overinvestment of enterprises.

Influence of executive team tenure heterogeneity on the relationship between equity incentive and overinvestment. According to the theory of social identity, the difference in tenure of senior management team members in the company will lead to different decision-making behaviors. Driven by the desire for self-expression, the members of the executive team with short tenure tend to ignore the investment risks of the enterprise and make adverse investment decisions when facing the equity incentive, thus leading to excessive investment. However, the long-serving executive team members have a full understanding of the corporate culture and philosophy, can rationally weigh the advantages and disadvantages in the face of equity incentive, and make reasonable decisions between risks and investment returns, so as to curb the excessive investment behavior of enterprises (Zhang Zhaoguo et al., 2013). Therefore, an executive team composed of members with different terms can complement each other in terms of social experience and practical ability through mutual communication and learning (Bai Jingkun et al., 2017). Under the equity incentive system, it may help to make rational decisions and thus reduce the excessive investment behavior of enterprises. Gao Changyuan and Wu Min (2019) believe that the longer a senior executive's tenure, the more skilled he or she is in the skills required for the position and the stronger his or her ability to analyze and solve problems. The heterogeneity of tenure of senior executives can inhibit enterprise risk behaviors and promote the healthy development of enterprises. Li Duansheng and Wang Xiaoyan (2019) believe that with the extension of the tenure of senior executives, the more familiar they are with the enterprise, and the greater the heterogeneity of tenure, the innovation investment activities of enterprises can be promoted to a certain extent. Based on this, this paper puts forward the following hypothesis

Hypothesis5: The greater the heterogeneity of the tenure of senior management teams, the greater the influence of equity incentive on the overinvestment of enterprises will be.

\section{Empirical design and model construction}

\subsection{Sample selection and data sources}

In this paper, data of Shanghai and Shenzhen A-share listed companies from 2014 to 2018 are selected as samples, and ST and *ST companies as well as companies with serious index missing or abnormal data in the total sample are excluded, and A total of 2993 observed values are finally obtained in 5 years. The sample data is mainly from THE CSMAR database. The statistical software for data processing and analysis in this paper is STATA 14.

\subsection{Variable design}

For the explained variable overinvestment, Richardson's (2006) model and method are mainly used in this paper. For the regression results of the model, the sign of the residual term is positive, that is, overinvestment. The explanatory variable, namely the measure index of equity incentive, is the management shareholding ratio (MR).

$$
\begin{gathered}
\operatorname{Inv}_{i, t}=\alpha_{0}+\alpha_{1} \text { Growth }_{i, t-1}+\alpha_{2} \text { Lev }_{i, t-1}+\alpha_{3} \text { Cash }_{i, t-1}+\alpha_{4} \text { Age }_{i, t-1}+\alpha_{5} \text { Size }_{i, t-1}+\alpha_{6} \text { Ret }_{i, t-1}+ \\
\alpha_{7} \text { Inv }_{i, t-1}+\sum \text { Year }+\sum \text { Industry }+\varepsilon
\end{gathered}
$$

Then, this paper selected four heterogeneity of senior executives' gender, age, education background and tenure to investigate their moderating effect on equity incentive and investment efficiency, and studied and designed relevant variables of heterogeneity of senior executives' teams. In addition, this paper selects board structure, revenue growth rate, asset-liability ratio, cash flow level, listing years, enterprise asset scale, stock return rate, industry and year as control variables, and the specific variables are defined in Table 1.

Table 1 Variable definitions

\begin{tabular}{ccl}
\hline variable & symbol & \multicolumn{1}{c}{ Variable definitions } \\
\hline Excessive investment & OI & Calculated according to model (1) \\
Equity incentive & MR & Total number of managerial holdings/total equity of the \\
& & company
\end{tabular}




\begin{tabular}{|c|c|c|}
\hline Gender heterogeneity & Hgen & Herfindahl index is used for calculation \\
\hline Age heterogeneity & Hage & $\begin{array}{l}\text { The standard deviation of the age of the executive team/the } \\
\text { mean of the age of the executive team }\end{array}$ \\
\hline $\begin{array}{l}\text { Educational } \\
\text { heterogeneity }\end{array}$ & Hedu & Herfindahl index is used for calculation \\
\hline Term heterogeneity & Htime & $\begin{array}{l}\text { Standard deviation of executive team tenure/mean of } \\
\text { executive team tenure }\end{array}$ \\
\hline Board structure & Dsize & $\begin{array}{l}\text { The proportion of independent directors on the board of } \\
\text { directors }\end{array}$ \\
\hline Revenue growth rate & Growth & $\begin{array}{l}\text { The ratio of the increase in operating income of this year to } \\
\text { the total operating income of the previous year }\end{array}$ \\
\hline Asset-liability ratio & Lev & Total liabilities/initial total assets \\
\hline Cash flow level & Cash & Ending monetary capital/total assets \\
\hline $\begin{array}{l}\text { Fixed number of year of } \\
\text { the listed }\end{array}$ & Age & The length of time a company has been listed \\
\hline $\begin{array}{l}\text { Total assets of the } \\
\text { enterprise }\end{array}$ & Size & The natural $\log$ of the total assets, $\operatorname{Ln}($ Size $)$ \\
\hline Stock return & Ret & The annual return on the company's stock \\
\hline $\begin{array}{l}\text { Industry dummy } \\
\text { variable }\end{array}$ & $\sum$ Industry & Dummy variable \\
\hline Annual dummy variable & $\sum$ Year & Dummy variable \\
\hline
\end{tabular}

\subsection{Model construction}

According to the research hypothesis of this paper, the following regression models (2) and (3) are constructed. Model (2) is used to study the influence of equity incentive on inefficient investment. Model (3) studies the influence of equity incentive on inefficient investment with the heterogeneity of senior management team as the regulating variable.

$$
\begin{aligned}
& \mathrm{OI}_{i, \mathrm{t}}=\alpha+\beta_{1} \text { MR }_{i, t}+\beta_{2} \text { Lev }_{i, t-1}+\beta_{3} \text { Ret }_{i, t-1}+\beta_{4} \text { Growth }_{i, t-1}+\beta_{5} \text { Cash }_{i, t-1}+\beta_{6} \text { Dsize }_{i, t-1}+ \\
& \beta_{7} \text { Size }_{i, t-1}+\beta_{8} \text { Age }_{t-1}+\sum \text { Industry }+\sum \text { Year }+\varepsilon \\
& \mathrm{OI}_{i, \mathrm{t}}=\alpha+\beta_{1} M R_{i, t}+\beta_{2} \text { Hgen }_{i, t}+\beta_{3} \text { Hage }_{i, t}+\beta_{4} \text { Hedu }_{i, t}+\beta_{5} H \text { time }_{i, t}+\beta_{6} \text { Hgen }_{i, t} \times \mathrm{MR}_{i, t}+ \\
& \beta_{7} \text { Hage }_{i, t} \times \mathrm{MR}_{i, t}+\beta_{8} \text { Hedu }_{i, t} \times \mathrm{MR}_{i, t}+\beta_{9} H \text { time }_{i, t} \times \mathrm{MR}_{i, t}+\beta_{10} \text { Lev }_{i, t-1}+\beta_{11} \text { Ret }_{i, t-1}+ \\
& \beta_{12} \text { Growth }_{i, t-1}+\beta_{13} \text { Cash }_{i, t-1}+\beta_{14} \text { Dsize }_{i, t-1}+\beta_{15} \text { Size }_{i, t-1}+\beta_{16} \text { Age }_{t-1}+\sum \text { Industry }+ \\
& \sum \text { Year }+\varepsilon
\end{aligned}
$$

\section{Empirical test and result analysis}

\subsection{Descriptive statistics}

Table 2 Descriptive statistics

\begin{tabular}{lccccc}
\hline variable & Sample size & The average & $\begin{array}{c}\text { The standard } \\
\text { deviation }\end{array}$ & The minimum value & $\begin{array}{c}\text { The } \\
\text { maximum }\end{array}$ \\
\hline OI & 2993 & 0.0425 & 0.0462 & 0.000015 & 0.289 \\
MR & 2993 & 0.130 & 0.182 & 0 & 0.663 \\
Hgen & 2993 & 0.260 & 0.169 & 0 & 0.750 \\
Hage & 2993 & 0.146 & 0.0527 & 0 & 0.323 \\
Hedu & 2993 & 0.592 & 0.181 & 0 & 0.889 \\
Htime & 2993 & 0.674 & 0.279 & 0 & 1.637 \\
\hline
\end{tabular}

According to Table 2, the maximum value of overinvestment is 0.289 , and the minimum value is 0.000015 . There is a big difference in overinvestment among different enterprises. By comparing the heterogeneity in the senior management team, it is found that the gender heterogeneity in the senior management team is large, indicating that the ratio of male to female in the senior management team is not coordinated, and the proportion of male executives may be higher. The age heterogeneity among senior executives was the lowest, indicating that the age distribution of senior executives in the sample was relatively concentrated. The average 
value was 0.592. Most of the degrees were bachelor's degree. However, there was a big difference between the maximum value and the minimum value, indicating the diversity of executive education. Tenure heterogeneity is the largest among senior management teams, with the maximum value reaching 1.637 and the minimum value only being 0 , indicating that the company is constantly introducing new senior management members. Based on the above situation, we can draw the conclusion that the heterogeneity of the senior management team of listed companies in China is quite different.

\subsection{Regression analysis}

\subsubsection{The regression result of equity incentive to inefficient investment}

Table 3 Analysis of regression results of equity incentive on inefficient investment

\begin{tabular}{cc}
\hline variable & OI \\
\hline \multirow{2}{*}{ MR } & $-0.0239^{* *}$ \\
& $(0.00518)$ \\
Growth & 0.00145 \\
& $(0.00105)$ \\
Size & $-0.0189^{* *}$ \\
& $(0.00327)$ \\
Lev & $-0.0184 *$ \\
& $(0.00749)$
\end{tabular}

$\begin{array}{cc}\text { Cash } & 0.120^{* * *} \\ & (0.0101) \\ \text { Age } & -0.0664 \\ & (0.0525) \\ \text { Ret } & 0.00582^{* *} \\ & (0.00141) \\ \text { Dsize } & 0.0210^{* *} \\ & (0.00447) \\ \text { Constant } & 1.043^{*} \\ \text { Industry } & (0.443) \\ \text { Year } & \text { Control } \\ \mathrm{N} & \text { Control } \\ \end{array}$

Table 3 shows the regression results of equity incentive and overinvestment, from which it can be seen that equity incentive and overinvestment are significantly negatively correlated, indicating that the greater the intensity of equity incentive, the more significant the inhibition effect of equity incentive on overinvestment behavior of senior executives is. Equity incentive can make the personal interests of managers and enterprise development objectives consistent, improve the efficiency of investment. It verifies that hypothesis 1 equity incentive can restrain the excessive investment behavior of senior executives.

\subsubsection{Heterogeneity of executive team and regression results of equity incentive and inefficient investment}

Table 4 Regression analysis of heterogeneity of senior management team, equity incentive and overinvestment

\begin{tabular}{|c|c|c|c|c|}
\hline variable & OI & OI & $\mathrm{OI}$ & OI \\
\hline $\mathrm{MR}$ & $\begin{array}{c}-0.038 * * \\
(-5.57)\end{array}$ & $\begin{array}{l}0.029 \\
(1.66)\end{array}$ & $\begin{array}{l}0.025 \\
(0.61)\end{array}$ & $\begin{array}{c}-0.039 * * \\
(-3.49)\end{array}$ \\
\hline $\begin{array}{c}\text { Hgen } \\
\text { Hgen } \times \text { MR }\end{array}$ & $\begin{array}{c}-0.005 \\
(-0.68) \\
0.046^{*} \\
(2.43)\end{array}$ & & & \\
\hline Hage & & $\begin{array}{l}-0.009 \\
(-0.57)\end{array}$ & & \\
\hline Hage $\times M R$ & & $\begin{array}{c}-0.299 * \\
(-3.13)\end{array}$ & & \\
\hline Hedu & & & $\begin{array}{l}0.007 \\
(1.25)\end{array}$ & \\
\hline Hedu $\times$ MR & & & $\begin{array}{l}-0.073 \\
(-1.24)\end{array}$ & \\
\hline Htime & & & & $\begin{array}{c}-0.010 * * * \\
(-9.74)\end{array}$ \\
\hline Htime $\times \mathrm{MR}$ & & & & $\begin{array}{l}0.024 \\
(1.78)\end{array}$ \\
\hline Growth & $\begin{array}{l}0.001 \\
(1.32)\end{array}$ & $\begin{array}{l}0.001 \\
(1.40)\end{array}$ & $\begin{array}{l}0.001 \\
(1.38)\end{array}$ & $\begin{array}{l}0.002 \\
(1.46)\end{array}$ \\
\hline Size & $\begin{array}{c}-0.019 * * * \\
(-5.85)\end{array}$ & $\begin{array}{c}-0.019 * * \\
(-5.70)\end{array}$ & $\begin{array}{c}-0.019 * * \\
(-5.75)\end{array}$ & $\begin{array}{c}-0.019 * * \\
(-5.76)\end{array}$ \\
\hline Lev & $\begin{array}{c}-0.018^{*} \\
(-2.44)\end{array}$ & $\begin{array}{c}-0.019 * \\
(-2.47)\end{array}$ & $\begin{array}{c}-0.019^{*} \\
(-2.49)\end{array}$ & $\begin{array}{c}-0.018^{*} \\
(-2.48)\end{array}$ \\
\hline Cash & $\begin{array}{c}0.119 * * * \\
(11.28)\end{array}$ & $\begin{array}{c}0.119 * * * \\
(11.81)\end{array}$ & $\begin{array}{c}0.119 * * * \\
(12.45)\end{array}$ & $\begin{array}{c}0.119 * * * \\
(11.50)\end{array}$ \\
\hline Age & -0.070 & -0.066 & -0.063 & -0.057 \\
\hline
\end{tabular}




$\begin{array}{cc}\text { Ret } & 0.006^{* *} \\ & (4.21) \\ \text { Dsize } & 0.022^{* *} \\ & (4.72) \\ \text { Constant } & 1.080 \\ \text { Year } & (2.19) \\ \text { Industry } & \text { Control } \\ \mathrm{N} & \text { Control } \\ & 2,993\end{array}$

Table 4 shows the regression results of the influence of equity incentive on overinvestment under the regulation of heterogeneity of senior management teams. The following results can be obtained from Table 4:

TMT heterogeneity of gender and equity incentive pay by a significant positive correlation with excessive investment, shows that executive team gender heterogeneity of equity incentive and overinvestment negative correlation between the positive regulatory role, namely executive gender heterogeneity, the greater the can enhance the effect of equity incentive to excessive investment, contrary to hypothesis 2 . The reason may be that executives of different genders have different styles of doing things. They learn from each other and learn from each other, which strengthens the role of equity incentive on excessive investment.

Age heterogeneity of senior management teams and the cross-multiplier of equity incentive are significantly negatively correlated with overinvestment, indicating that the effect of equity incentive on overinvestment is influenced by age heterogeneity of senior management teams, and age heterogeneity of senior management teams will weaken the influence of equity incentive on overinvestment, which is contrary to hypothesis 3 .The reason may be that senior executives with high age heterogeneity are prone to conflict in decision-making due to large differences in experience and knowledge, which weakens the inhibitory effect of equity incentive on overinvestment.

There was no significant regression result between the educational heterogeneity of executive team and the cross-product of equity incentive and overinvestment, indicating that there was no significant correlation between the inhibitory effect of equity incentive on overinvestment and the educational heterogeneity of executive team, which was inconsistent with hypothesis 4.

The heterogeneity of tenure in senior management teams and the cross-product term of equity incentive and the regression results of overinvestment were not significant, indicating that the inhibition effect of equity incentive on overinvestment was not significantly correlated with the heterogeneity of educational background of senior management teams, which was inconsistent with hypothesis 5 .

\section{Research conclusions and countermeasures}

The results show that:(1) equity incentive can restrain

$\begin{array}{ccc}(-1.32) & (-1.23) & (-1.07) \\ 0.006^{* *} & 0.006^{* *} & 0.006^{* *} \\ (3.99) & (4.29) & (4.20) \\ 0.026^{* *} & 0.022^{* *} & 0.023^{* *} \\ (4.49) & (4.60) & (5.66) \\ 1.037^{*} & 1.006^{*} & 0.973 \\ (2.47) & (2.39) & (2.18) \\ \text { Control } & \text { Control } & \text { Control } \\ \text { Control } & \text { Control } & \text { Control } \\ 2,993 & 2,993 & 2,993\end{array}$

the excessive investment behavior of senior executives.(2) The greater the age heterogeneity of the senior management team is, the impact of equity incentive on overinvestment will be weakened.(3) The greater the gender heterogeneity of the senior management team, the greater the influence of equity incentive on overinvestment.(4) The heterogeneity of education and tenure in senior management teams did not affect the relationship between equity incentive and overinvestment. Accordingly, this paper proposes the following suggestions:

Improve the gender diversity of the company's executive team members. When selecting members of the senior management team, both male and female executives should be employed. Gender should not be too single, so that senior management team members can learn different working styles from each other, learn from each other's strengths and make joint decisions conducive to the long-term development of the company and improve the company's efficiency.

Build a senior executive team with a reasonable age. Senior executives of different ages have different understandings of the enterprise. New and old senior managers working together tend to have conflicts in thinking mode and values, which is not conducive to the internal unity of the senior management team. For the long-term and stable development of the company, senior executives of similar age can work together as much as possible, which is conducive to narrowing the thinking gap, improving the efficiency of communication, and making decisions more rational and effective, so as to better restrain the occurrence of excessive investment and improve the investment efficiency of the company.

\section{Acknowledgements}

We would like to thank the participants of the 2021 International Conference on industrial technology and engineering management for their comments and comments. Finally, we would also like to thank the Ministry of education for its funding: the humanities and social sciences research project of the Ministry of Education (Project No. 16XJA790007).

\section{References:}

1. BelghitarY, ClarkE. Managerial risk incentives and inverstment related agency costs[J]. International Review of Financial Analysis, 2015(38): 191-197. 
2. Liu Yawei. Heterogeneity of Executive team, Promotion Incentive and Inefficient Investment [J]. Financial Journal,2015(11).

3. Lin Chaonan. Background characteristics of Managers and Enterprise Investment Efficiency -Empirical Evidence from China's Listed companies [J]. Journal of Xiamen University (Philosophy and Social Sciences edition), 2014(02):100-109.

4. Bai Jingkun, Li Hongyan, Qu Lingxia. How the heterogeneity of the executive team of listed companies affects strategic Change in a dynamic Environment - An empirical analysis based on the data of some listed on the Shanghai and Shenzhen Stock Exchanges [J]. Macroeconomic Research, 2017(02):157-168.

5. Sheikh S. Do CEO compensation incentives affect firm innovation? [J]. Review of Accounting and Finance, 2012, 11(1): p.4-39.

6. Song Yuchen, Qiao Muzi, Li Lianwei. Empirical Study on the Influence of Equity Incentive on investment efficiency of Listed Companies [J]. Economic Review,2017(05):105-111.

7. Wang Luping, Baiyinhuan, Wang Yintian. The Influence of Equity Incentive on Investment Efficiency -- Based on the Empirical Analysis of Listed Family Enterprises [J]. Systems Engineering, 2012, 36(08):37-50.

8. Wang Zeyuan, Cao Yang. Empirical Research on the Influence of Executive Compensation Incentive, Equity Incentive and Non-efficient Investment in pharmaceutical manufacturing enterprises [J]. Modern Trade and Industry,2020, 41(17):102-104.

9. Yang Kun, GU Ying, ZHAO Jiarene. A Study on the Influence of Executive Heterogeneity on Corporate Overinvestment -- Based on the Mediating effect of Pay Gap [J]. Journal of China university of petroleum (social sciences edition), 2019, 35(04):24-34.

10. Gao Changyuan, Wu Min. Research on the Influence of Executive Team heterogeneity on Corporate Performance -- Based on the moderating effect of Salary gap $[\mathrm{J}]$. Science, technology and management,2019,21(01):33-40.

11. Yang L, Wang D. The impacts of top management team characteristics on entrepreneurial strategic orientation: The moderating effects of industrial environment and corporate ownership[J]. Management Decision, 2014, 52(2):378 - 409.

12. Sun Yemeng, Zhang Guitong. A test of the relationship between overconfidence of managers, financial flexibility of enterprises and overinvestment $[\mathrm{J}]$. Statistics and decision- making, 2020, 36(06):178-181. 